\title{
The Impact of Worker's Remittances on Economic Growth in Egypt (1991-2016)
}

Prof. Dr. Mohamady Fawzy Metwally Professor of economics Faculty of economic studies\& political science Alexandria University
Dr. Gehad Ahmed Nour El Dine

Assistant professor of economics

Faculty of commerce

Sadat-city University 


\section{Summary:}

The main goal of this study is to investigate the effect of remittances relative to the other macroeconomic variables such as foreign direct investment, investment, government expenditure and labor on the economic growth in Egyptian economy. The results show that remittances do have negative impact on the growth of the GDP per capita of Egypt.

This paper has tried as well to identify the policies that Egyptian government could implement if it wants to motivate their migrants to transfer more money and to invest these remitted money in productive projects. Identifying the current implemented policies and evaluating whether these policies have succeeded to create an attractive economic environment for investors in general and for migrants in specific or not, will be subject to further research.

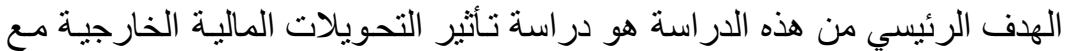

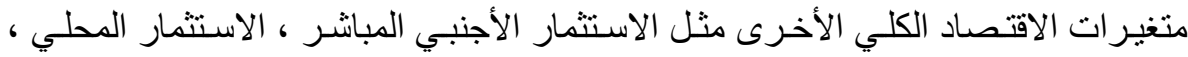

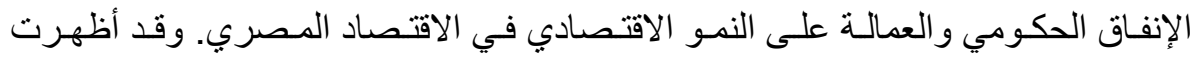

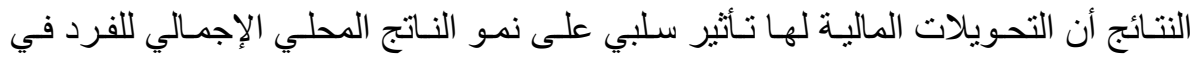

مصر . n

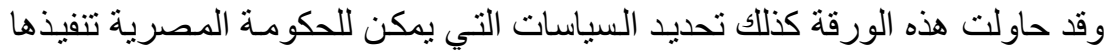

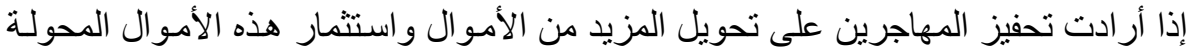

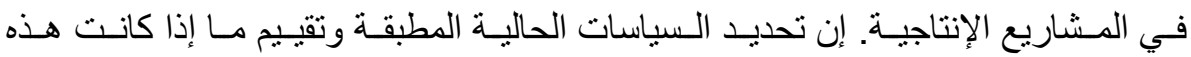

السياسات قد نجت في خلق بيئة اقتصادية جذابة للمستثمرين بشكل عام وللمهاجرين بشكل

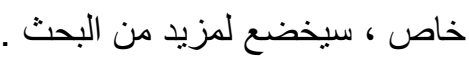

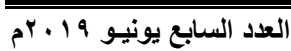

( 2 )

مجلة الدراسات التجارية المعاصرة 


\section{Introduction:}

Workers' remittances in emerging and developing countries particularly are important source of income. During recent decades, workers' remittances were increasing rapidly and played important role in the development of different countries around the world. The volume of the world remittances has jumped from $\$ 3.6$ billion to $\$ 514$ billion during period ( $1970-2012$ ), while the volume of remittances to developing countries has gone up from $\$ 61.6$ billion in 1990 , to $\$ 111.3$ billion in 2000 and about $\$ 377$ billion in 2012 .

Egypt is one of the world's leading labor exporting countries. Until 1971, emigration from Egypt was subject to legal restrictions and limited numbers, especially upon professionals who could migrate permanently to the West. Egypt is currently experiencing what has been called the permanence of temporary migration, whereby migration towards Arab countries is becoming less temporary and outnumbers long term migration to Europe, North America, Australia, and Japan. Recently, a rise in mostly irregular migration to Europe, especially to Italy and France, has also been recorded, according to the official statistics; 6.5 million Egyptian nationals live abroad, representing approximately $8 \%$ of total population.(CAPMS, 2010)

Egyptian workers' remittances flows increased from \$2.696 billion in 1980 to $\$ 4.05$ billion in 1990 and to $\$ 7.9$ billion in 2011 which represents $3.4 \%$ of GDP.( IMF, balance of payment). It reached a maximum value of $\$ 8.7$ billion in 2008 , and a minimum value of $\$ 927.6$ million in 1977. Although the remittances of Egyptian workers are flows of private capital, they are substantially affected by number of economic and political factors.

By stating the importance of remittances to solve some of the economic problems that both developing and developed countries are suffering from, we need to see whether remittances along with other variables have the same positive impact on Egypt's economic growth or not. But, due to the literature limitation in addressing specific country's characteristics and conditions in relative to the variables that best affect the country's economic growth, this study will try to fill this gap by using an econometric model that can help to analyze the impact of remittances along with other variables on growth of GDP for a recipient country, in our case Egypt. Since most of the studies tackled Egypt for instance as one of the countries in a statistical panel while ignoring its unique economic features.

\section{Literature review:}

Many economists have realized several large empirical studies on various aspect of remittance, such as motivation of remittance

مجلة الاراسات التجارية المعاصرة


senders, impact of remittance on economic growth, cost of remittance, etc. There are diverse opinions on the impact of remittances on economic growth.

\section{Remittances impact on economic growth}

An appropriate understanding of remittances relationship can help policy makers to design a suitable economic policy. There are three types of theoretical models used in literature to study the effects of remittances on economic growth. These theoretical strands are: those arguing that remittances have a positive impact on the economic growth, those explaining negative effects on the economy and then the other combining the above two competing arguments as follows:

\section{The positive effects of remittances on economic growth}

Workers' remittances have positive effects on the growth of their home country through the following: The transmitted funds can feed the productive investment, and that in two manners:- first, if these funds are deposited in banks or in local institutions of savings, by increasing the financial resources of these institutions for granting the credit to the companies or for short or long term loans granted by non banking financial institutions to companies or households; second, when the families of the emigrated workers encounter difficulties of credit rationing, the remittances enable them to circumvent these difficulties and are able to finance their needs for consumption or their capital expenditures.

(Rapoport and Docquier, 2006) argue that due to the liquidity constraints, remittances could affect investments and human capital formation. Therefore, remittances tend to have an overall positive effect on origin countries' long-run economic performance. (Faini R, 2002) observes that the impact of financial flows on economic growth depends on growth prospects and the investment climate in migrant home countries. He argues that worker remittances serve as a means to counter financial stocks such as crops failures and adverse trading and to maintain consumption levels. In the study of (Stahl and Arnold,1986) they argue that remittances have possible multiplier effect due to spending on consumption purposes; therefore, they may have positive effect on growth. (Adams, 1998) observes that inward remittances have positive impact on domestic savings, economic investment, and enhance economic growth, where workers' remittances serve a dual role in recipient countries, both enhancing the productive capacity of the economy and generating greater demand.

The remittances can also contribute to develop the financing capacities of the financial system, in the home economy, in particular

العدد السابع يونيو 19.19
(4)
مجلة الدراسات التجارية المعاصرة 
in its banking component; and we know, as it has been shown in numerous endogenous growth models, that the enhancing of the financial system in developing or emerging countries is an important factor of growth. (Bugamelli and Paterno, 2005) underline that remittances can have a beneficial effect if they reduce the probability that foreign investors suddenly flee out of emerging markets or developing economies; they consider that there is a threshold effect of remittances: if remittances are over 3\% of GDP, they can be considered as cheap inflows of foreign currencies which gives guarantees to the foreign investors present in the country. In (Sufian, 2009) reports the positive direct and indirect impact of remittances on the economic growth, through their interactions with financial and institutional channels. With the regression of panel data for 7 MENA countries during the period (1975-2006). (Giuilano and Arranz , 2005) observe that worker remittances have positive impact on economic growth because they facilitated credit access among the poor and aid in the development of the financial sector. In the study of( Jongwanich,2007) using panel data for 17 countries in the Asian and Pacific region for the period (1993-2003). He finds that the remittances may have indirect impact on economic growth through household credit availability, also he finds that remittances have significant influence on poverty reduction and increase standard of living.

In (Michael A. Clemens and David McKenzie, 2014) While measured remittances by migrant workers have soared in recent years, macroeconomic studies have difficulty detecting their effect on economic growth. They review existing explanations for this puzzle and propose three new ones. First, they offer evidence that a large majority of the recent rise in measured remittances may be illusoryarising from changes in measurement, not changes in real financial flows. Second, they show that even if these increases were correctly measured, cross-country regressions would have too little power to detect their effects on growth. Third, they point out that the greatest driver of rising remittances is rising migration, which has an opportunity cost to economic product at the origin. Net of that cost, there is little reason to expect large growth effects of remittances in the origin economy. Migration and remittances clearly have first-order effects on poverty at the origin, on the welfare of migrants and their families, and on global GDP; but detecting their effects on growth of the origin economy is likely to remain elusive.

In (Shera A and Meyer D, 2013) The main goal of this study is to investigate the effect of remittances relative to the other external 
sources of capital such as foreign direct investment on the economic growth in Albanian economy. The results show that remittances do have positively impact on the growth of the GDP per capita of Albanian country. We have found that a 1 percent increase in remittances lead to a 0.14 percent increase in the GDP per capita income.

The negative impacts of remittances on economic growth

These negative effects can be gathered and analyzed around

\section{Three analytical topics:}

First: the mechanical monetary consequences of the entry of foreign currencies in a low developed country open to the movements of capital (through their effects on the exchange rate of the local currency and on the domestic price level).

Second: the uses of these incomes either within the family of the migrant worker (ostentatious consumption expenditure), or by the worker himself who chooses to spend his savings through land acquisitions or real estate investment.

Third: the effect of the remittances can be also negative in terms of incentives to network (or to less work) among the members of the family remained in home country or to encourage them (and also some neighbors) for a new wave of emigration.

The impact of workers' remittances may have also a negative impact on the local income distribution inequality as shown in (Adams' and Richard's 2008) paper and these inequalities among families with or without emigrate members abroad, lead to two types of further inequalities and negative incentives. Nowadays the same story happens: (Van Dalen, Groenewald and Fokkema, 2005) in an empirical study for Egypt, Turkey and Morocco, show also that the receipt of remittances in the home country of emigrants has an attractive effect on emigration intentions of household members living home; this trigger-effect is a truly negative effect in terms of labor force disposal for economic development in the home country. This contribution of the receipt of remittances to new flows of migration seems to be particularly high in Morocco.

(Chami et al, 2003) use the World Bank aggregate panel data for 113 countries for the period (1970-1998). They analyze the causes and effects of workers' remittances, and they find a negative and significant relationship between the growth of remittances and the GDP growth rate. They also find that remittances differ greatly from private flows in terms of motivation and their effects and they conclude that remittances do not appear to be significant source of 
capital for economic development, and it could also decrease economic growth through a Dutch disease effect.

( Emmanuel et al, 2010) use unbalanced panel data set comprising 109 developing and transition countries for the period (1990-2003). They find "Dutch disease" effects of rising levels of remittances in these emerging economies.

The mixed impacts of remittances on economic growth Some empirical studies found that the remittances either have mixed effects or have no effects on economic growth such as:

( Habib and Nourin, 2006 ) observe that the impact of worker remittances on economic growth are mixed in South and South East Asian economies. They find that there is negative relationship between migrant remittance and per-capita GDP growth in Thailand, Srilanka, India and Indonesia, whereas this relationship is positive in Bangladesh, Pakistan and Philippines. (Adolfo et al, 2009) run regression analysis of OLS with instrumental variables and fixed effects model for the sample of data comprising 84 recipient countries with annual observations for the years (1970-2004), they find that remittances have contributed little to the economic growth in remittance receiving economies and may have retarded growth in some.

In a study conducted by ( IMF, 2005 ) about the impact of remittances on growth over an extended period (1970-2003) for 101 developing countries finds no statistical link between remittances and per capita output growth, or between remittances and other variables such as education or investment rates. However, this inconclusive result attributed to measurement difficulties arising from the fact that remittances may behave countercyclical with respect to growth.

From the above, we can say the different positive or negative effects of remittances on macroeconomic performance analyzed above show that these specific financial funds, contrary to FDI and portfolio inflows, do not insure economic growth. In this paper, we will examine the impact of worker s remittance in Egypt on economic growth either positive or negative effects.

1-2-Thesis Problem:

Since 1970s, Remittance inflow became a phenomenon that has received much attention from considerable number of scholars, researchers and policy makers due to its importance as a source of international capital flows as well as due to its stable nature compared to other flows such as; FDI, foreign loans, etc. Given the possible impact that these remittances could have on the growth and development of developing countries, a number of studies have been 
carried out to test the impact of remittances on the receiving country's economy and still there is a debate among scholars and researchers about whether remittances have a significant and positive impact on economic growth or not.

Therefore, this study will focus to test the relationship between remittances and Egyptian economic growth along with the help of other macroeconomic variables.

\section{Thesis hypothesis:}

Observing the increasing remittance income many researchers or policy makers have been showing interest to examine its impact on economic growth in both the host country and the home country of the migrant workers. Regarding the impact of remittances in the home country of migrant workers, there is debate; some argue that remittances have a positive impact on economic growth and some argue it has negative impact on economic growth. In most of the previous studies have been established the null hypothesis as a statement of correlation and not causation. Now question is whether remittances are a statistically significant factor in determining economic growth and whether the relation between remittances and economic growth is causal. So it is very important to study further in a particular country regarding the linkage between remittance income and economic growth. So here in this paper Egypt has been chosen to find out the relation between remittances and Gross Domestic Product (GDP).

\section{Trends of remittance in Egypt:}

Egypt is one of the world's leading labor exporting countries. The mix of Egyptian emigrants includes labor of almost all professions and specializations, emigrants spread all over the world. Within the Middle East Egyptians migrate largely to the oil-producing countries of the Gulf and Libya, and to a lesser degree to Lebanon and Jordan. Outside the Middle East, Egyptians migrate to the United States, Europe, Canada, Australia, and Japan. Emigration to oilproducing countries is always "temporary," as residency laws in these countries deny permanent residency to emigrants. Egyptian emigrants who seek permanent residency abroad have no choice but to go to countries where such residency is permissible, in particular to Australia, European countries, and the United States. However, given that labor markets in these countries are highly competitive, only skilled emigrants are able to emigrate to them and receive residency privileges. Essentially, this is a form of the "brain drain" from which Egypt has been suffering. By contrast, most of the Egyptian workers who immigrate to oil-producing countries in the region are less skilled العدد السابع يونيو 19. 19 
and of lower educational levels, including teachers and clerical and construction workers. All those are temporary migrants, i.e., they have a target level of savings that they seek to achieve and then return to Egypt with those savings.

Figure (1) shows the evolution of Egyptian migrant remittances during the period from 1985 to 2000. Emigrant remittances increased from $\$ 3.21$ billion in 1985 to $\$ 8.56$ billion in 2008 , before falling to $\$ 7.8$ billion in 2009 as a result of the financial crisis. Although the remittances of Egyptian migrants are flows of private capital, they are substantially affected by a number of economic and political factors. For example, the exceptionally high levels of remittances in 1992 and 1993, which reached $\$ 6.1$ billion and $\$ 5.66$ billion, respectively, reflected the developments in the immediate post-Gulf War period, when the Gulf States decided to replace large numbers of Jordanians, Palestinians, Sudanese, and Yemeni workers with Egyptian labor. During the period of 1985-2009, the average annual migrant remittances were about $\$ 4.22$ billion.

There is no doubt that the evolution of remittances reflects, in addition to economic and political factors, changes in stocks of migrant workers abroad, especially those of temporary emigrants with low skills, who tend to be in high demand in the Arab oil-producing countries in times of expansion. The stock of skilled labor is more stable both in the oil-producing countries and in industrial countries.

In 2009 workers' remittance decreased to $\$ 7.15$ billion due to the global financial crises effects. Despite of the political events that happened in Egypt during January 2011, which led to economic instability and it reflected on all forms of economic life, the workers' remittances increased to $\$ 7.9$ billion by the end of 2011 .

The geographic distribution of the stock of Egyptian migrants abroad is reflected vividly in the sources of remittance flows to Egypt. Table 1 shows the flows of remittances from different immigration countries during the period from 1999 to 2009. It is clear that the United States is the largest source of remittances to Egypt. On average, one-third of all flows of remittances to Egypt are derived from the United States. As mentioned above, migration to the United States is mainly permanent. However, the problem with transfers from permanent migrants is their tendency to diminish, as linkages between emigrants and their country of origin weaken over time. The second generation is primarily associated with their places of birth and has almost no links with their countries of origin. Therefore, unless there is a continuous flow of new emigrants, remittances from permanent migrants eventually stop.

مجلة الاراسات التجارية المعاصرة


Figure 1: Total Remittances of Egyptian Migrants

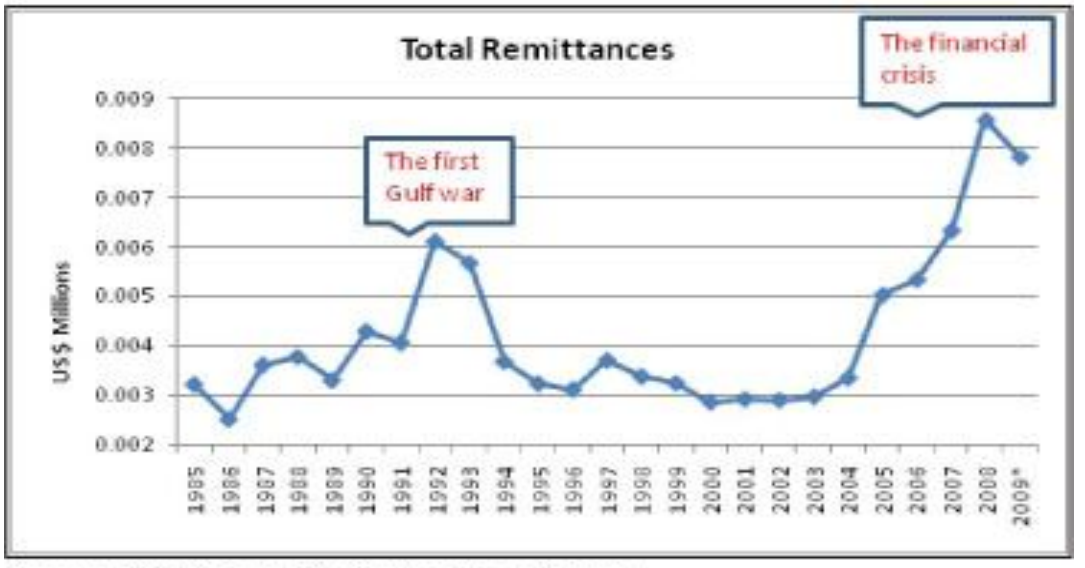

Source: UNCTAD and the Central Bank of Egypt

As a source of remittances to Egypt, and with respect to their relative importance, the Gulf States rank second. Egyptian workers transferred $\$ 1.5$ billion from the Gulf States in 1999/2000. Nearly ten years later, in 2008/2009, remittances have more than doubled to $\$ 4.15$ billion. Saudi Arabia had been the most important source of remittances for Egypt until 2004, ahead of the United Arab Emirates and Kuwait.

Since 2004, remittances from Kuwait have grown in an unprecedented manner to the extent that Kuwait has become the most important source of remittances from the Gulf to Egypt. Kuwait has witnessed a huge balance of payments (BOP) surplus and abundant foreign assets due to higher crude oil prices. Soaring oil revenues matched with the adoption of an ambitious plan to transform Kuwait into a financial center resulted in an explosion in construction and infrastructure projects, which in turn drove labor demand in these sectors. This demand has been primarily met from Egypt or from the stock of Egyptians working in the neighboring countries. The substantial rise in the number of Egyptian workers in Kuwait has caused a dramatic increase in remittances to Egypt. In 2007/2008, $\$ 1.79$ billion were remitted from Kuwait alone, which represented nearly $20 \%$ of total remittances flowing to Egypt from abroad, compared to \$1.38 billion from the United Arab Emirates and \$959.4 million from Saudi Arabia. As such, Kuwait has become the second largest source of remittances to Egypt after the United States, as shown in figure (2). 
Figure (2) Remittance inflows to GDP for Egypt

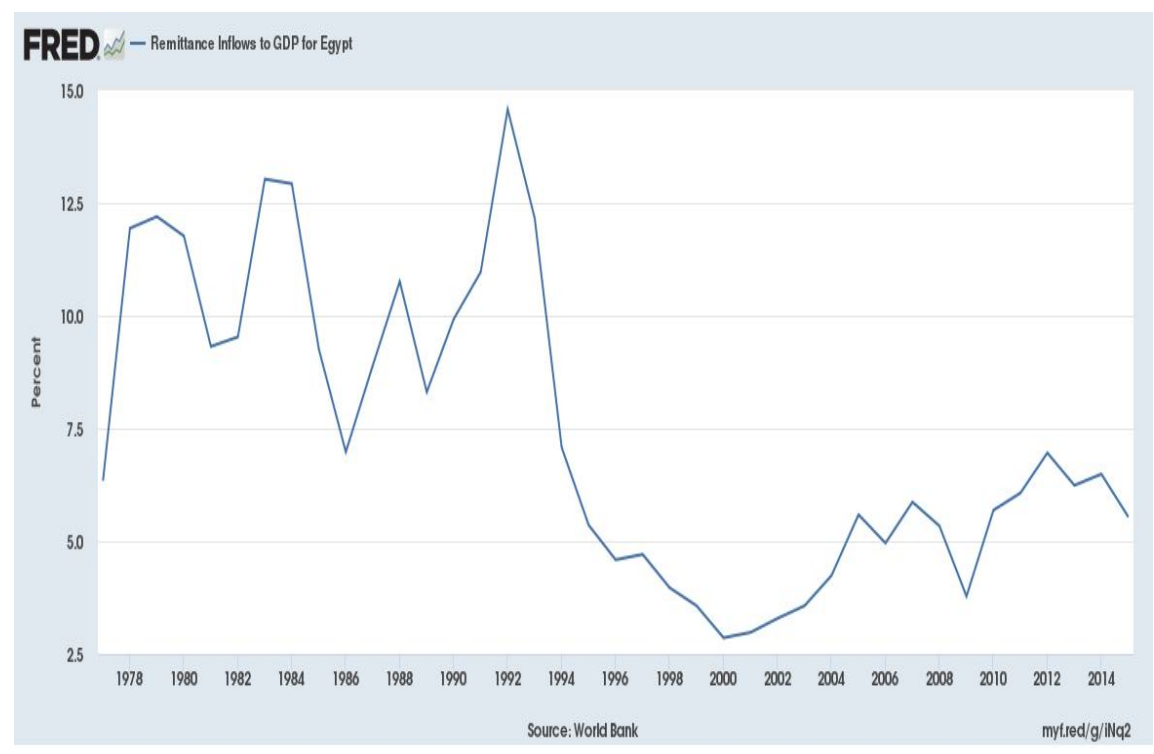

Source: world Bank data

\section{The Importance of Remittances to the Egyptian Economy}

The significance of remittances to the country of origin could be assessed on the basis of several indicators, including the proportion of remittances to GDP. Figure (2) shows the proportion of migrant remittances to Egyptian GDP. As a percentage of GDP, remittances reached a peak during the first Gulf War, with an inflow accounting for about $15 \%$. On average, during the period of $1985-2009$, the ratio of remittances to GDP has been about 5.9\%. On the other hand, the average remittances per capita peaked in 2008, (at about $\$ 105$ ). The average annual remittances per capita during 1985-2009 have been around $\$ 61.4$. These figures may seem to be low, but if the average number of family members per emigrant is taken into account, in addition to the average per capita income in the country, these numbers become quite significant at the household level.

Until 1994, the remittance flows had exceeded the value of Egyptian exports of goods. Starting from this year (with the exception of 1998), the proportion of remittances to Egyptian exports has continuously declined, reaching its lowest level in 2008, which corresponded to $32.6 \%$ of total exports. During the period of 19852009 , the average ratio of remittances to total exports was at around $105 \%$. In 1991, remittance flows to Egypt amounted to 16 times the FDI inflow. During the period of 1985-2006, the average proportion of remittances to the FDI inflow was about $482 \%$. Remittance flows also were more than five times that of official foreign aid. During the العدد السابع يونيو 19.19 
period 1985-2006, the average percentage of remittances to the total official foreign aid was about $210 \%$.

Figure (3): the average percentage of remittances To the total official foreign aid

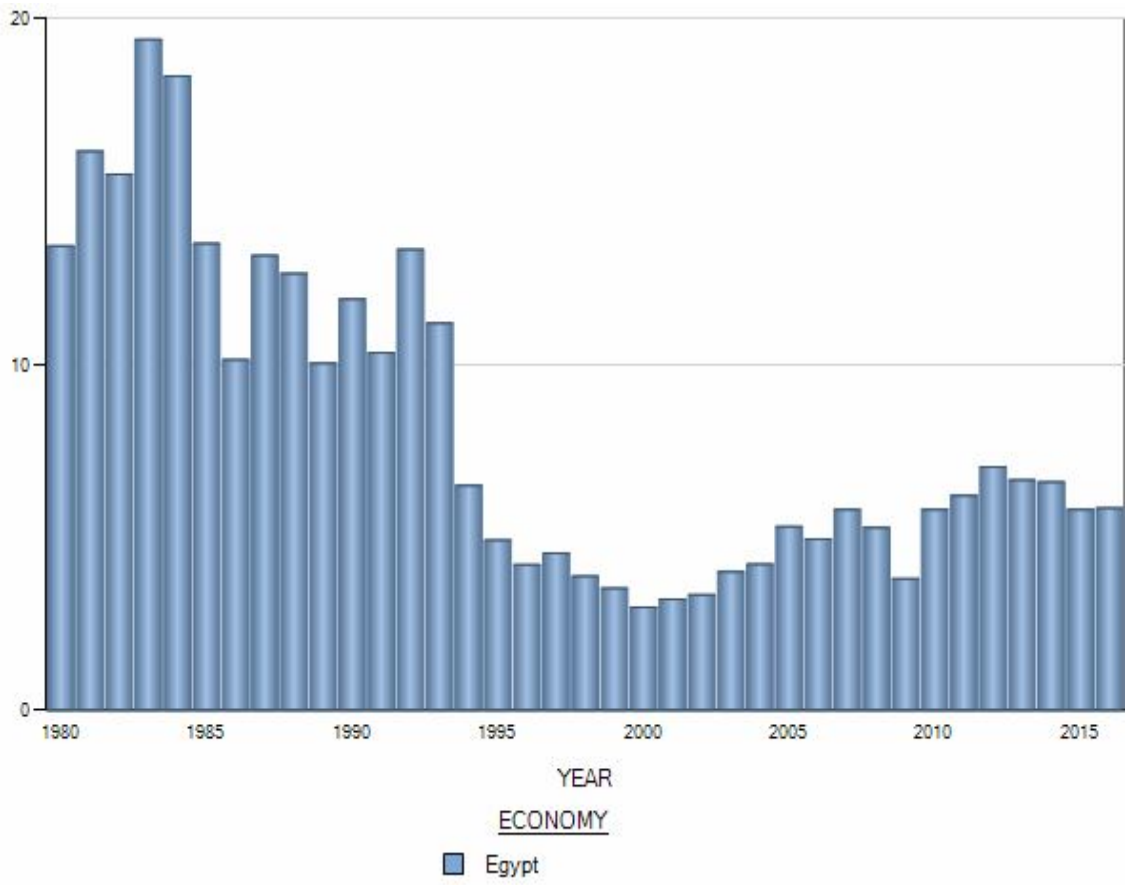

Source: world Bank data

The previous analysis reveals that migrant remittances are vital to the Egyptian economy. Therefore, policymakers must deal with remittances with extreme caution in order to ensure the stability of the foreign exchange market and the Egyptian pound.

Econometric model and Methodology:

Data:

The study will use time series data for testing the relationship between economic growth (GDP\% annual) and workers' remittances as one of the major macroeconomic variables in Egypt. The included variables in this study are: workers' remittances, Gross Domestic Product (GDP), private investment in physical capital formation, government spending, foreign direct investment, government expenditure, The data for the period (1991-2016) are taken from the world Banks, World Development indicators, IMF balance of payment statistics yearbook, the World Economic Outlook database, and Central Bank of Egypt annual reports. The variables are in real terms $(2000=100)$, we have used the Multiple Linear regression Model to test the relationship between the dependent variable (GDP) and other

العدد السابع يونيو 19. 19. 
independent variables in which an ordinary least squares regression analysis will be used.

This study will examine the relationship between economic growth and workers' remittances in Egypt, by estimating the following model:

Where :

$$
\begin{gathered}
Y=f(w r, f d i, i . g . l) \\
Y \text { it }=\beta 0 i+\beta 1 w r i t-1+\beta 2 \text { fdiit }+\beta 3 i i t+\beta 4 \text { git }+ \\
\beta 5 \text { l it }+\eta \mathbf{i}+\varepsilon \text { i }
\end{gathered}
$$

\section{(Y) GDP growth (annual \%)}

Annual percentage growth rate of GDP at market prices based on constant local currency. Aggregates are based on constant 2010 U.S. dollars. GDP is the sum of gross value added by all resident producers in the economy plus any product taxes and minus any subsidies not included in the value of the products. It is calculated without making deductions for depreciation of fabricated assets or for depletion and degradation of natural resources.

\section{(I) Gross capital formation (\% of GDP)}

Gross capital formation (formerly gross domestic investment) consists of outlays on additions to the fixed assets of the economy plus net changes in the level of inventories. Fixed assets include land improvements (fences, ditches, drains, and so on); plant, machinery, and equipment purchases; and the construction of roads, railways, and the like, including schools, offices, hospitals, private residential dwellings, and commercial and industrial buildings. Inventories are stocks of goods held by firms to meet temporary or unexpected fluctuations in production or sales, and "work in progress." According to the 1993 SNA, net acquisitions of valuables are also considered capital formation.

(G) General government final consumption expenditure(\% of GDP)

General government final consumption expenditure (formerly general government consumption) includes all government current expenditures for purchases of goods and services (including compensation of employees). It also includes most expenditure on national defense and security, but excludes government military expenditures that are part of government capital formation.

(WR)Personal remittances, received (\% of GDP)

Personal remittances comprise personal transfers and compensation of employees. Personal transfers consist of all current transfers in cash or in kind made or received by resident households to or from nonresident households. Personal transfers thus include all current transfers between resident and nonresident individuals.

مجلة الاراسات التجارية المعاصرة


Compensation of employees refers to the income of border, seasonal, and other short-term workers who are employed in an economy where they are not resident and of residents employed by nonresident entities. Data are the sum of two items defined in the sixth edition of the IMF's Balance of Payments Manual: personal transfers and compensation of employees.

\section{(FDI) Foreign direct investment, net inflows (\% of GDP)}

Foreign direct investment are the net inflows of investment to acquire a lasting management interest (10 percent or more of voting stock) in an enterprise operating in an economy other than that of the investor. It is the sum of equity capital, reinvestment of earnings, other long-term capital, and short-term capital as shown in the balance of payments. This series shows net inflows (new investment inflows less disinvestment) in the reporting economy from foreign investors, and is divided by GDP.

\section{(L) Employment to population ratio, 15+, total (\%) (modeled ILO estimate)}

Employment to population ratio is the proportion of a country's population that is employed. Employment is defined as persons of working age who, during a short reference period, were engaged in any activity to produce goods or provide services for pay or profit, whether at work during the reference period (i.e. who worked in a job for at least one hour) or not at work due to temporary absence from a job, or to working-time arrangements. Ages 15 and older are generally considered the working-age population.

\section{Metadata:}

In general, a large $\mathrm{J}-\mathrm{B}$ value indicates that errors are not normally distributed.

A result of 1 means that the null hypothesis has been rejected at the $5 \%$ significance level. In other words, the data does not come from a normal distribution. A value of 0 indicates the data is normally distributed. From table (1) we can see that (fdi) and (wr) does not come from a normal distribution and all other variables are normally distributed. 


\begin{tabular}{|c|c|c|c|c|c|c|}
\hline \multicolumn{7}{|c|}{ Table (1) Metadata } \\
\hline & $\bar{L}$ & $\overline{I I}$ & $\bar{G}$ & FDI & WR & $\overline{Y Y}$ \\
\hline Mean & 242.48462 & 18.40923 & 111.40385 & 2.305231 & 8.626923 & 4.206538 \\
\hline Median & 42.45000 & 18.45000 & 11.30000 & 1.252500 & 5.400000 & 4.335000 \\
\hline Maximum & 44.80000 & 22.40000 & 12.80000 & 9.344000 & 20.00000 & 7.158000 \\
\hline Minimum & 40.60000 & 13.80000 & 10.20000 & -0.205000 & 3.800000 & 1.079000 \\
\hline Std. Dev. & 1.088740 & 2.382162 & 0.759200 & 2.485645 & 3.389579 & 1.609200 \\
\hline Skewness & 0.324171 & -0.338756 & 0.310677 & 1.786841 & 2.695084 & 0.071786 \\
\hline Kurtosis & 2.343535 & 2.286113 & 2.402586 & 5.186969 & 10.57744 & 2.444164 \\
\hline Jarque-Bera & 0.922235 & 1.049378 & 0.804898 & 19.01688 & 93.67738 & 0.357030 \\
\hline Probability & 0.630578 & $\begin{array}{r}0.591739 \\
\end{array}$ & $\begin{array}{r}0.668680 \\
-\end{array}$ & 0.000074 & 0.000000 & 0.836512 \\
\hline Sum & 1104.600 & 478.6400 & 296.5000 & 59.93600 & 172.3000 & 109.3700 \\
\hline $\begin{array}{l}\text { Sum Sq. } \\
\text { Dev. }\end{array}$ & 29.63385 & 141.8674 & 14.40962 & 154.4607 & 287.2312 & 64.73813 \\
\hline Observations & 26 & 26 & 26 & 26 & 26 & 26 \\
\hline
\end{tabular}

Source: Preparing by the researcher using the statistical program (Eviews)

The Unit Root Test (UR) (Test Root Unit) is used to determine the stability of string data Time of the different variables in the model and at which level of differences this stability is achieved, and to be sure of the absence of variables whose rank of integration is (2) or higher, and table (2) summarizes the results to test the root of the unit (UR) for variables in their original form or after differences. Through: ADF (Fuller-Dickey Augmented), Phillips Peron (Perron-Phillips) (PP), using the statistical program (Eviews)

Table (2) Stability of the model (UR) By using Augmented DickeyFuller test \& Phillips-Perron test

\begin{tabular}{|c|c|c|c|c|c|c|c|c|}
\hline \multirow{3}{*}{$\begin{array}{c}\text { Variabl } \\
\text { es }\end{array}$} & \multicolumn{4}{|c|}{ The variables in its original level } & \multicolumn{4}{|c|}{ The variables in its $1^{\text {st }}$ difference } \\
\hline & \multicolumn{2}{|c|}{$\begin{array}{c}\text { Augmented } \\
\text { Dickey-Fuller }\end{array}$} & \multicolumn{2}{|c|}{ Phillips-Perron } & \multicolumn{2}{|c|}{$\begin{array}{c}\text { Augmented } \\
\text { Dickey-Fuller }\end{array}$} & \multicolumn{2}{|c|}{ Phillips-Perron } \\
\hline & $\begin{array}{c}\text { consta } \\
\text { nt }\end{array}$ & $\begin{array}{c}\text { Consta } \\
\text { nt\& } \\
\text { trend } \\
\end{array}$ & $\begin{array}{c}\text { consta } \\
\text { nt }\end{array}$ & $\begin{array}{c}\text { Consta } \\
\text { nt\& } \\
\text { trend } \\
\end{array}$ & $\begin{array}{c}\text { Consta } \\
\text { nt }\end{array}$ & none & $\begin{array}{c}\text { Consta } \\
\text { nt }\end{array}$ & none \\
\hline Y & $\begin{array}{l}-2.08 \\
(0.09)\end{array}$ & $\begin{array}{l}-2.06 \\
(0.19)\end{array}$ & $\begin{array}{l}-3.22 \\
(0.00)\end{array}$ & $\begin{array}{l}-3.17 \\
(0.01)\end{array}$ & $\begin{array}{l}-2.73 \\
(0.00)\end{array}$ & $\begin{array}{l}-2.65 \\
(0.00)\end{array}$ & $\begin{array}{l}-6.06 \\
(0,00)\end{array}$ & $\begin{array}{l}-5.89 \\
(0.00)\end{array}$ \\
\hline WR & $\begin{array}{l}-3.53 \\
(0.00)\end{array}$ & $\begin{array}{l}-3.27 \\
(0.00)\end{array}$ & $\begin{array}{l}-7.06 \\
(0.00)\end{array}$ & $\begin{array}{l}-6.26 \\
(0.00)\end{array}$ & $\begin{array}{l}-2,40 \\
(0.00)\end{array}$ & $\begin{array}{l}-1.77 \\
(0.00)\end{array}$ & $\begin{array}{l}-8.61 \\
(0.00)\end{array}$ & $\begin{array}{l}-9.09 \\
(0.00)\end{array}$ \\
\hline FDI & $\begin{array}{l}-2.77 \\
(0.00)\end{array}$ & $\begin{array}{l}-2.82 \\
(0.01)\end{array}$ & $\begin{array}{l}-2.07 \\
(0.10)\end{array}$ & $\begin{array}{l}-2.05 \\
(0.26)\end{array}$ & $\begin{array}{l}-2.98 \\
(0.00)\end{array}$ & $\begin{array}{l}-2.92 \\
(0.04)\end{array}$ & $\begin{array}{l}-3.14 \\
(0.00)\end{array}$ & $\begin{array}{l}-3.07 \\
(0.02)\end{array}$ \\
\hline G & $\begin{array}{l}-2.08 \\
(0.13)\end{array}$ & $\begin{array}{l}-1.88 \\
(0.26)\end{array}$ & $\begin{array}{l}-1.82 \\
(0.10)\end{array}$ & $\begin{array}{l}-1.98 \\
(0.23)\end{array}$ & $\begin{array}{l}-3.11 \\
(0.00)\end{array}$ & $\begin{array}{l}-3.12 \\
(0.00)\end{array}$ & $\begin{array}{l}-4.59 \\
(0.00)\end{array}$ & $\begin{array}{l}-4.52 \\
(0.00)\end{array}$ \\
\hline I & $\begin{array}{l}-1.75 \\
(0.21) \\
\end{array}$ & $\begin{array}{l}-2.68 \\
(0.08) \\
\end{array}$ & $\begin{array}{l}-1.76 \\
(0.12) \\
\end{array}$ & $\begin{array}{l}-2.33 \\
(0.12) \\
\end{array}$ & $\begin{array}{l}-3.65 \\
(0.00) \\
\end{array}$ & $\begin{array}{l}-3.59 \\
(0.00) \\
\end{array}$ & $\begin{array}{l}-4.28 \\
(0.00) \\
\end{array}$ & $\begin{array}{l}-4.21 \\
(0.00) \\
\end{array}$ \\
\hline $\mathrm{L}$ & $\begin{array}{l}-1.45 \\
(0.27)\end{array}$ & $\begin{array}{l}-2.39 \\
(0.11)\end{array}$ & $\begin{array}{l}-1.89 \\
(0.07)\end{array}$ & $\begin{array}{l}-3.07 \\
(0.01)\end{array}$ & $\begin{array}{l}-4.07 \\
(0.00)\end{array}$ & $\begin{array}{l}-3.97 \\
(0.00)\end{array}$ & $\begin{array}{l}-5.81 \\
(0.00)\end{array}$ & $\begin{array}{l}-5.70 \\
(0.00)\end{array}$ \\
\hline
\end{tabular}

Source: Preparing by the researcher using the statistical program (Eviews) 
From table (2) we observe the following:

* All variables are stationary in (PP) test and (AUD) test in the first difference with $p$ value equal zero.

* (Y),(WR),(FDI) are stationary variables with (AUD) and (PP) test

(G),(I),(L) are trend stationary.

\section{Co integration test:}

Co- integration will be detected to determine whether there is a long-term relationship between the variables Model, or not, using the JML, using two tests: Test Trace- (Max) (Test Value Eigen). These two tests are conducted to test the nudity that there is a maximum of (r) of the relationships of the common integration between the variables of the model, where (r) expresses the number of relations of co-integration between variables, and zero equals the absence of any common integration relationship between the variables of the form or Is equal to $1,2, .$. , a maximum of $(1-\mathrm{k})$, where $\mathrm{k}$ is the number of variables in the model, which is six variables.

Table (3) co integration test

\begin{tabular}{|ccccc||}
\hline $\begin{array}{c}\text { 1 Percent } \\
\text { Critical Value }\end{array}$ & $\begin{array}{c}\text { 5 Percent } \\
\text { Critical Value }\end{array}$ & $\begin{array}{c}\text { Trace } \\
\text { Statistic }\end{array}$ & Eigenvalue & $\begin{array}{c}\text { Hypothesized } \\
\text { No. of CE(s) }\end{array}$ \\
\hline \hline 90.45 & 82.49 & 94.25716 & 0.808308 & None ** \\
66.52 & 59.46 & 54.61240 & 0.542319 & At most 1 \\
45.58 & 39.89 & 35.85440 & 0.496691 & At most 2 \\
29.75 & 24.31 & 19.37717 & 0.372921 & At most 3 \\
16.31 & 12.53 & 8.176792 & 0.263934 & At most 4 \\
6.51 & 3.84 & 0.822324 & 0.033683 & At most 5 \\
\hline \hline *(**) denotes rejection of the hypothesis at the 5\%(1\%) level & \\
Trace test indicates 1 co integrating equation(s) at both 5\% and 1\% levels \\
\hline
\end{tabular}

Source: Preparing by the researcher using the statistical program (Eviews)

It is clear from this table that there is a phenomenon of joint integration between the variables of the model according to both tests; this means that there are relationships that balance the model variables in the long term. It is refused to impose Nullity there is no correlation between the model variables in the face of the alternative hypothesis of a relationship one common integration at a significant level of 1 percent according to the two tests, and nullification is rejected

One common integration relationship in the face of alternative imposition with a relationship of common integration between the variables of the model

According to the tests at a significant level of 1 percent, The imposition of nihilism is also rejected by the existence of a common integration relationship in the face of the alternative hypothesis, there are three common integrative relationships between the model

مجلة الاراسات التجارية المعاصرة


variables according to the two tests a significant 1 percent according to the two tests, and even five joint integration relationships according to the first test only, and three according to the second test. Thus, this result allows the next step to be done, the ones that are represented by measuring these relationships; they represent the long-term balance between model variables.

\section{Estimating the relationships between variables:}

Stated earlier, we have used the Multiple Linear regression Model to test the relationship between the dependent variable (GDP) and other independent variables such as remittances, FDI, Investment, government expenditure and labor in which an ordinary least squares regression analysis will be used. The result of the chosen statistical model is shown in the below:

$$
\begin{gathered}
Y=-0.2193508791 * W R+0.3335580767 * F D I+0.2141543712 * I \\
-0.3236867229 * G+0.1091714504 * L
\end{gathered}
$$

\begin{tabular}{|c|c|c|}
\hline Variables & Coefficient & p-value \\
\hline WR & $\mathbf{- 0 . 2 1 9 3 5 1}$ & $\mathbf{0 . 0 0 1 1}$ \\
\hline FDI & $\mathbf{0 . 3 3 3 5 5 8}$ & $\mathbf{0 . 0 0 0 3}$ \\
\hline I & $\mathbf{0 . 2 1 4 1 5 4}$ & $\mathbf{0 . 0 1 5 9}$ \\
\hline G & $\mathbf{- 0 . 3 2 3 6 8 7}$ & $\mathbf{0 . 1 8 1 8}$ \\
\hline L & $\mathbf{0 . 1 0 9 1 7 1}$ & $\mathbf{0 . 1 9 2 4}$ \\
\hline
\end{tabular}

Estimating the model:

\begin{tabular}{||c|c|}
\hline Model & \\
\hline \hline R-squared & 0.722904 \\
\hline Adjusted R-squared & 0.670124 \\
\hline Durbin-Watson stat & 1.629771 \\
\hline Observations & 26 \\
\hline
\end{tabular}

Source: Preparing by the researcher using the statistical program(Eviews)

By analyzing the above model results, we could see that the estimated model shows high correlation between variables and this is shown in the high $\mathrm{R}$ square and adjusted $\mathrm{R}$ square with about 0.722 and 0.670 respectively. This means that the data obtained have highly fit in the statistical model and that $67 \%$ of the variance in the observed values of the dependent variable (GDP) is explained by the independent variables chosen in this model, which are remittances, investment, FDI, government expenditure and labor. Besides, the estimated model as a whole is significant as indicated by the significance DW (1.629). We have 26 observations in this model which represent the data collected from 1991-2016. 
Regarding the total investment variable, we could see that the model results have asserted the hypothesis of the paper that there is a strong positive relationship between investment variable and GDP with a $p$ value of 0.015 . As stated earlier, this result seems to be relatively realistic and logic since investment is one of the important variables that have a direct effect on GDP. And this assumption is asserted by the results of our estimated statistical model as well as through the empirical studies done by several other researchers such as; (Mundaca, 2009; Burgess \& Haksar,2005; Iqbal and Satar,2005; waqas 2013), which proved there is a strong positive significant relationship between investment and economic growth. That's why we could deduct that investment is considered to be a corner stone in boosting and improving the economic development in Egypt.

Moving to the Foreign direct investment variable, we could see that there is a strong significant positive relationship between FDI variable and GDP with a $\mathrm{p}$ value of 0.000 , which verified the hypothesis that there will be strong and positive relationship between the two variables. This result seems to be rational since FDI is considered to be one of the variables that could have a direct effect on GDP in any country especially in a developing country such as; Egypt. And this positive impact was asserted by the results of the estimated statistical model as well as in different practical researches that have proved the strong relationship between both variables performed by different researchers such as; (Sachs and Warner, 1999; Edwards, 1998).

Moreover, we could see that there is an insignificant negative relationship between government expenditure variable and GDP with a $\mathrm{p}$ value of 0.181 , and a negative coefficient of 0.323 . Similarly, the labor variable is insignificant but with positive relationship with GDP with a $p$ value of 0.192 , and a positive coefficient of 0.109 . That's why we could deduct that government expenditure and labor are considered to be insignificant in boosting and improving the economic development in Egypt.

Finally, we can see that the estimated statistical model has showed a negative relationship between remittances, our main concerned variable in this research paper, and GDP, with negative coefficients about (-0.219) but it showed significant $P$ value with about (0.001), which actually contrast the main hypothesis initiated that there is a negative and significant relationship between the two variables.

مجلة الاراسات التجارية المعاصرة"


However, this negative effect could be justified due to several reasons. One of these reasons is the lack of data availability and inability to report all the remittances that enter the country in both formal and informal channels. This limitation has made us in this statistical model focus only on the formal recorded remittances that have entered the country through formal channels such as; banks, posts and money transfers enterprises such as; Western union. However, the model does not take into account the unrecorded remittances that enter the country through informal channels such as; sending the money through hand delivery by either a trusted friend or a relative who was visiting the migrant household.

The second reason is the difference between the official bank exchange rates and the black market exchange rate, which makes migrants and other people encouraged to sell their foreign currencies in the black market rather than the banks to get advantage of the difference between the two rates. For example, on February 3rd 2015, the black market money dealers stated that they are buying "dollars at the official exchange rate of 7.63 Egyptian Pounds and the pound was trading at an average of 7.982 to the dollar in the black market" (Namatalla, 2015). This difference in the exchange rates have increased the amount of unrecorded remittances and the money coming from unofficial channels, which have deprived the country from getting use of this money in investing in productive projects that could have a positive impact on GDP or to stabilize its balance of payments by increasing its foreign reserves.

The third reason is that although remittances seem to be relatively steady source of foreign currency in Egypt even in the most difficult periods that Egypt has suffered from, however; these remittances have not been invested in productive projects that could have positive impact on GDP. This assumption was asserted by the survey on the 200 households that showed that most of the remittances go to consumption rather than investment. Besides, several researchers have showed that most of the remittances are used mainly for consumption purposes rather than investment purposes in several countries including Egypt.

The effect of remittances in the economic growth depends on the way which they are spent. If remittances are spent for consumption, the welfare impact of remittances depends on the relative factor intensities of traded and non-traded goods. The empirical evidence indicates that multiplier effects can substantially increase gross national product. 
If remittances generate demand greater than the economy's capacity to meet this demand, and this demand falls on non-tradable goods, remittances can have an inflationary effect. In Egypt, for example, the price for agricultural land rose between 1980 and 1986 by $600 \%$ due to remittances. Along with the positive effects remittances had on Jordan's economy, in the years 1985, 1989 and 1990, they seem to have intensified recession very strongly and generated negative growth rates of over $10 \%$.

Other potential negative welfare implications of remittances are the encouragement of continued migration of the working age population and the dependence among recipients accustomed to the availability of these funds. All these could perpetuate an economic dependency that undermines the prospects for development.

Finally, because remittances take place under asymmetric information and economic uncertainty, it could be that there exists a significant moral hazard problem leading to a negative effect of remittances on economic growth. Given the income effect of remittances, people could afford to work less and to diminish labor supply. Using panel methods on a large sample of countries found that remittances have a negative effect on economic growth (which according to the authors indicates that the moral hazard problem in remittances is severe).

The long-run motivation for attracting increased remittance inflows is to promote economic growth and development in recipient countries. In line with this ambition, understanding of the appropriate channels through which remittances influence economic performance is essential to formulating sound policies to maximize their overall impact on an economy. The major potential channels of the positive effects of remittance inflows on the growth and development prospects of developing economies include how these remittances impact on domestic investment, balance of payments, ease domestic credit constraints, exports, diversification of economic activities, levels of employment and wages, human capital development and technological progress. On the contrary, remittance inflows may also have adverse effects on the growth and development prospects of developing economies in a number of ways.

One of the critical negative effects of increased remittance inflows on a developing economy is the infection of the Dutch Disease through reduction in international competitiveness. A continuous and significant inflow of remittances can lead to increase in demand for the domestic currency. This increase in demand for non-tradable may further lead to the appreciation of the domestic currency, hence real العدد السابع يونيو 19.19 
appreciation of the exchange rate, which in turn reduces the international competitiveness of the country's exports whilst imports are made relatively cheaper. In effect, remittances may, through a number of mechanisms, exacerbate the balance of payments position in the long run, later, have argued that remittances undermine productivity and growth in low-income countries because they are readily spent on consumption likely to be dominated by foreign goods than on productive investments. Theoretically, the degree of impact of remittance inflows on external competitiveness of a receivingdeveloping country may vary depending upon some specific characteristics. For instance, because unemployment is high in many developing countries, there may not be any significant increase in the production costs of export commodities even in the face of an increased demand for non-tradable.

\section{Statistics Tests:}

\section{Residual graph:}

A residual graph is a graph that shows the residuals on the vertical axis and the independent variable on the horizontal axis. If the points in a residual plot are randomly dispersed around the horizontal axis, a linear regression model is appropriate for the data; otherwise, a non-linear model is more appropriate.

Below, the residual plots shows a random pattern, indicating a good fit for a linear model.

\section{Graph (4) Residual graph}

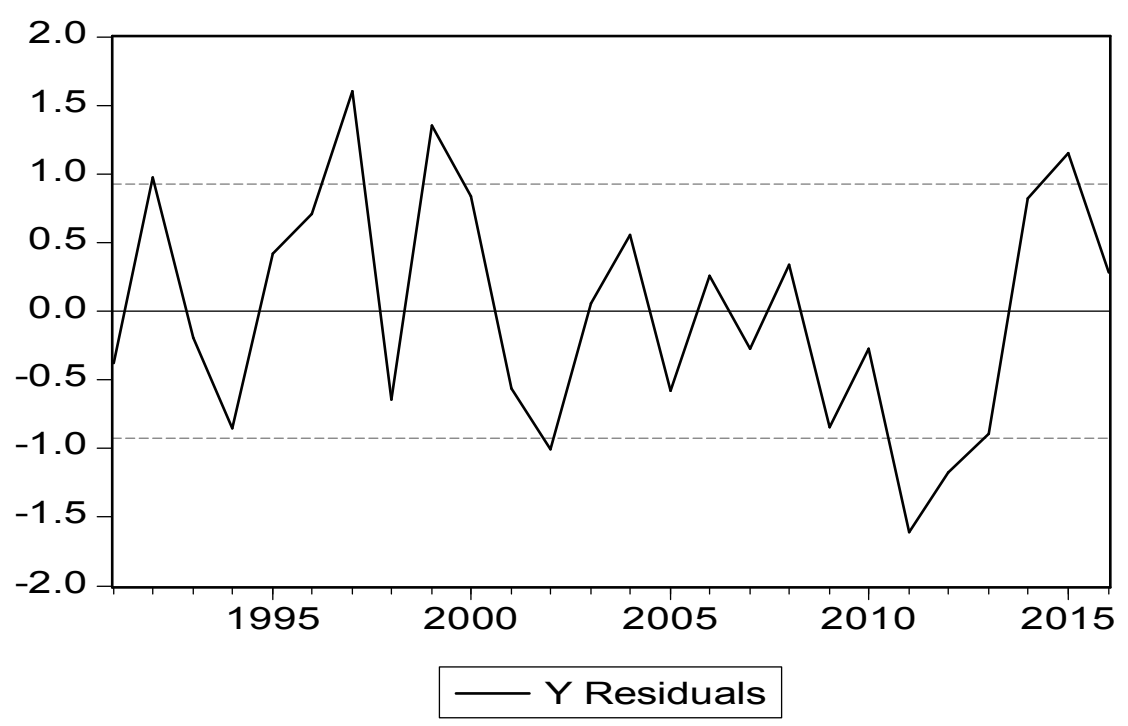

Source: Preparing by the researcher using the statistical program (Eviews) 


\section{Correlogram of residuals:}

The Durbin-Watson (DW) statistic as a part of the standard regression output. The Durbin-Watson statistic is a test for first-order serial correlation. More formally, the DW statistic measures the linear association between adjacent residuals from a regression model.

If there is no serial correlation, the DW statistic will be around 2. The DW statistic will fall below 2 if there is positive serial correlation (in the worst case, it will be near zero). If there is negative correlation, the statistic will lie somewhere between 2 and 4 .

Positive serial correlation is the most commonly observed form of dependence. In our regression ( $\mathrm{DW}=1.629$ ), for this reason we will display the autocorrelation and partial autocorrelation functions of the residuals, together with the Ljung-Box Q-statistics for high-order serial correlation. If there is no serial correlation in the residuals, the autocorrelations and partial autocorrelations at all lags should be nearly zero, and all Q-statistics should be insignificant with large pvalues as show in table (4).

Table (4) correlogram of residuals

\begin{tabular}{|c|c|c|c|c|c|c|}
\hline Prob & Q-Stat & $\begin{array}{l}\text { PAC } \\
\end{array}$ & $\mathbf{A C}$ & & Partial Correlation & Autocorrelation \\
\hline 0.334 & 0.9315 & 0.179 & 0.179 & 1 & $.1^{*}$. & $\left.\right|^{*}$. \\
\hline 0.628 & 0.9319 & -0.030 & 0.003 & 2 & 1 & .1 \\
\hline 0.712 & 1.3720 & -0.117 & -0.118 & 3 & $*$ & $* \mid$ \\
\hline 0.819 & 1.5429 & 0.120 & 0.072 & 4 & $.1^{*}$ &.$\left.\right|^{*}$. \\
\hline 0.755 & 2.6417 & -0.227 & -0.178 & 5 & $* * \mid$ & $*^{*} \mid$ \\
\hline 0.581 & 4.7165 & -0.194 & -0.239 & 6 & $* * \mid$ & $* * \mid$ \\
\hline 0.564 & 5.7954 & 0.320 & 0.168 & 7 & $\left.\cdot\right|^{* *}$. & $\left.\cdot\right|^{*}$ \\
\hline 0.655 & 5.9274 & -0.133 & 0.057 & 8 & $*$ & \\
\hline 0.745 & 5.9488 & -0.004 & 0.022 & 9 & & . \\
\hline 0.795 & 6.2362 & 0.044 & -0.079 & 10 & & $* *$ \\
\hline 0.802 & 6.9626 & -0.034 & 0.122 & 11 & &.$\left.\right|^{*}$. \\
\hline 0.664 & 9.4520 & -0.275 & -0.219 & 12 & $* *$ & $* * \mid$ \\
\hline
\end{tabular}

Source: Preparing by the researcher using the statistical program(Eviews)

\section{Policies to Attract Remittances:}

Emigration from developing countries to developed countries shows no signs of slowing in this era of globalization. While there are positive and negative aspects to emigration for both sending and receiving countries, developing countries, which are most likely to be labor-sending countries, should focus their attention on maximizing the benefits that accrue from the positive aspects of emigration. One of these positive aspects is remittances that working migrants send to relatives still living in their country of origin. While the amount of remittances a country realizes is dependent on many factors, the general trend in remittance inflows is that they are increasing. العدد السابع يونيو 19 19 
Developing countries, ready to explore every option available to increase their citizens' welfare, should focus on developing policies that maximize and channel this increasing flow of remittances.

\section{Factors that Influence Remittance Inflows:}

There are several factors that influence remittance inflows to developing countries. The first factor is the number of workers abroad. There is a positive correlation between the number of migrant workers abroad and the amount of remittances inflows. The second factor is the strength of the ties between the worker and his or her home country. This factor has two components. The longer workers are away from home, the weaker the ties with their country become and, consequently, the lower the remittance flows are on average. Similarly, the greater the number of females in the migrant population, the lower the remittances are on average. The third factor is the elasticity of real income in the host country. Finally, the fourth factor includes macroeconomic and portfolio concerns such as the relative rates of return in the country of origin, relative prices, and economic uncertainty. In terms of the macroeconomic climate, a rise in black market premium (defined as the difference between the black market exchange rate and the official exchange rate) by ten percent results in a decline in official remittances by three percent, according to a study of six major labor-exporting countries in North Africa and Europe. Furthermore, the domestic rate of inflation also has a significant negative effect on the flow of remittances. Economies that are weak or unstable discourage emigrant remittances.

\section{Policies to Maximize Remittance Inflows:}

Before considering specific policies, it is important for a country to have its economic house in order. This might be difficult for many developing countries, but is an essential prerequisite to maximize the benefits from particularized policies aimed at maximizing remittance inflows. Because uncertain macroeconomic conditions-such as high black market premiums, unfavorable exchange rates, and inflation-can have negative impacts on remittance inflows, they must be corrected before maximization policies are implemented. One way developing countries try to increase inflows is to require mandatory remittances by those working abroad.

Given the largely private nature of remittances, a more attractive way for governments to increase inflows is through incentive schemes. Perhaps the most widely used incentive scheme has been to allow workers to deposit remittances in repatriable foreign currency accounts with domestic banks. These accounts allow workers 
to deposit funds in banks located in their country of origin with the assurance that they will be able to withdraw the funds at their discretion. The decision by workers to utilize these accounts, however, is to a large extent dependent on the interest rate on these deposits as compared with interest rates in world capital markets. Moreover, repatriable foreign currency accounts are used only by professional and highly skilled workers who earn relatively higher incomes and have the means to assess investment opportunities and transfer excess income internationally.

Another available incentive-based policy is to offer premium exchange rates. Under this scheme, importers are able to use the foreign exchange they have purchased to import certain commodities regulated by import control authorities. The downside to this importlinked incentive scheme is that it remains attractive only so long as the government maintains a restrictive trade and payments regime.

In Egypt, seventy-three percent of expenditures by returning migrants went toward the purchase of agricultural or building land. To channel some of these investments away from land and into, for instance, agricultural productivity, the government will need to make the private rates of return on these investments more attractive by, for instance, continuing to raise its price support level for government supported crops like cotton, wheat, and rice. Adams notes, Once the private rates of return on these crops become more favorable, peasant migrants are likely to begin investing a larger share of their remittances monies in elements of the new agricultural technology, such as high-yielding seeds, fertilizers, and agricultural equipment. To the extent that such investment increases the incomes of peasant farmers, it may well provide an economic stimulus for other sectors of the rural, nonfarm economy. As the incomes of peasant farmers rise, they will have more to spend on health service and transport activities. The expansion of these and similar locally based activities could well provide a broad economic stimulus for developing rural Egypt from the local level up. Based on this example, commodity price support schemes appear to hold great potential for developing countries exploring ways to influence remittance use and modernize their agricultural base.

Unfortunately, when migration of Egyptian labor started to increase at the end of the 1960s and 1970s, Egypt had very strict rules in place regarding holding and dealing in foreign currencies, which led to a flourishing black market for foreign exchange. The black market had been the main venue of remittance flows explained by an 
undervalued pound. A very active network of black market agents collected currencies from Egyptians working abroad to be used, through informal channels, to finance the smuggling of foreign goods and other illicit trade activities.

To control the black market, the government attempted to reform gradually and partially its foreign exchange policy. In 1971, for example, individuals were granted the right to open special foreign exchange accounts in Egyptian banks. In 1973, a parallel market for foreign exchange was established with the intention of attracting the savings of emigrant workers by offering them incentive exchange rates. In 1974, emigrant workers were allowed to finance imports from abroad. In 1976, individuals were granted the right to hold foreign exchange and to deal in it through licensed banks. In 1977, privileges granted to foreign investors were extended to Egyptian investors to encourage emigrant workers to invest their savings in Egypt. Believing in the importance of migration to the Egyptian economy, the Ministry of Emigration and Working Abroad was established in 1981, which later merged with the Ministry of Labor to form the Ministry of Manpower and Emigration. During the period from 1983-1985, several foreign exchange premiums were granted to emigrants who converted their savings from abroad. Finally, in 1991 the government abolished the two-tier foreign exchange rate system and replaced it with the unified exchange rate. This resulted in the full liberalization of the Egyptian pound, thus avoiding any possible negative effects of the foreign exchange policy on the inflow of remittances.

\section{Conclusion and Recommendation:}

The main goal of this study is to investigate the effect of remittances relative to the other macroeconomic variables such as foreign direct investment, investment, government expenditure and labor on the economic growth in Egyptian economy. The results show that remittances do have negative impact on the growth of the GDP per capita of Egypt.

We have focused on Egypt since Egypt, like many other countries, is suffering from both economic and political conditions that are hindering its economic growth and its ability to compete with other developing countries such as; Brazil. And given the abundant resources that Egypt owns, however the Egyptian government has failed to use these resources to promote investments and to enhance the economic conditions. That's why in this paper, we will focus on remittances which considered to be a relative stable source of foreign currency that hasn't been affected by the political and economic conditions that Egypt is suffering from.

مجلة الاراسات التجارية المعاصرة"


This paper has tried as well to identify the policies that Egyptian government could implement if it wants to motivate their migrants to transfer more money and to invest these remitted money in productive projects. Identifying the current implemented policies and evaluating whether these policies have succeeded to create an attractive economic environment for investors in general and for migrants in specific or not, will be subject to further research.

Remittances are only one factor in the complex array of factors associated with the development of less developed countries, but they are a significant source of income for those with family members abroad, especially those living in impoverished rural areas. While, on average, remittances will likely never account for a large percentage of the capital investment needed to raise the living standards of those in less developed countries, the trends in remittance inflows indicate that policies to maximize remittances and channel them into productive uses should be seriously considered, especially by developing countries with significant numbers of workers abroad. 


\section{References}

1. Central Agency for Public Mobilization and Statistics (CAPMS), (2010). The Statistical Yearbook, Egypt.

2. International Monetary Fund (IMF), Balance of Payment Statistics Yearbook, Various issue

3. Rapoport, H., Docquier, F., (2006). The Economics of Migrants' Remittances. IZA discussion papers, Institute for the Study of Labor (IZA).

4. Faini R., (2002), Migration, Remittances and Growth, Brescia, University of Brescia, Italy

5. Stahl, Charles, and Fred Arnold,(1986), Overseas Workers' Remittances and Asian Development, International Migration Review 20 (4)

6. Adams R. H.,(1998). Remittances, Investment and Rural Asset Accumulation in Pakistan. Economic Development and Cultural Change, 47(1).

7. Bugamelli, M., Paterno, F., (2005). Do Workers' Remittances Reduce the Probability of Current Account Reversals?.World Bank Policy Research Working Paper (3766).

8. Sufian El-tayyeb, M., (2009). Workers' Remittances and Growth in MENA Labor Exporting Countries. International Network for Economic Research, Working Paper (10).

9. Giuliano, Paola, and Marta Ruiz-Arranz, (2005), Remittances, Financial Development, and Growth, IMF Working Paper (234)

10. Jongwanich, J., (2007). Workers' Remittances, Economic Growth and Poverty in Developing Asia and the Pacific countries. UNESCAP Working Paper, (1)

11. Shera, A. and Meyer, D. (2013) "Remittances and their impact on Economic Growth", Periodica Polytechnica Social and Management Sciences, 21(1), pp. 3-19.

12. Clemens, Michael A. and McKenzie, David J., Why Don't Remittances Appear to Affect Growth? (May 1, 2014). World Bank Policy Research Working Paper No. 6856. Available at SSRN: https://ssrn.com/abstract $=2433809$

13. Adams R. H., R. Cuecuecha, A and Page J. (2008), Remittances, Consumption and Investment in Ghana, Working Policy Paper (4515), World Bank Development Department and African Region, World Bank.

14. Van Dalen H.P., Groenewald G., Fokkema T., (2005), "Remittances and their Effects on Emigration Intention in Egypt, Morocco and Turkey", Tinbergen Institute Discussion Paper 05030/1, Tinbergen Institute. 
15. Chami R., Fullenkamp C., Samir J., (2003). Are Immigrant Remittance Flows a Source of Capital for Development?. IMF staff papers.52 (1).

16. Emmanuel L., Federico M., Acosta P., (2010). Remittances, Exchange rate regimes and the Dutch disease: A panel data analysis. Federal Reserve Bank of Atlanta working papers.

17. Habib, Md. R., Nourin, S., (2006). Remittances and Real Investment: an Appraisal on South and South East Asian Economies, Faculty of Economics. Chulalongkorn University, Asian Institute of Technology, Bangkok.

18. Adolfo Barajas, Ralph Chami, Connel Fullenkamp, Michael Gapen and Peter Montiel,(2009), Do workers' Remittances Promote Economic Growth, Internal Monetary Fund, Working Paper.(153).

19. International Monetary Fund (IMF), (2005).World Economic Outlook.

20. Waqas, Bin Dilshad.(2013) “Impact of Workers' remittances on Economic Growth: An Empirical Study of Pakistan's Economy". International Journal of $n$ Business and Management, 8 (24).

21. Sachs, Jeffrey D. and Andrew M. Warner. "The Big Rush, Natural Resource Booms And Growth," Journal of Development Economics, 1999, v59(1,Jun), 43-76.

Leading Issues in Economic Development, Oxford University Press, 2000.

22. Chimhowu A., Pinder C., Piesse J., (2003). Assessing the impact of Migrant Workers' Remittances on Poverty. Presented at New Direction in Impact Assessment for Development Methods and Practices. IDPM, University of Manchester, Kings College, London. Institute for Development Policy and Management. Wise Development LTD 24 - 25 November.

23. Chami, R., Barajas, A., Cosimano, T., Fullenkamp, C., Gapen, M. and Montiel, P., (2008). Macroeconomic Consequences of Remittances.IMF Occasional Paper (259), Washington DC.

24. Laura Ansala, (2012). Motives, Channels and Migration for Remittances: Evidence from Uganda, Senegal and Nigeria. Master Thesis in Economics, School of Economics, Aalto University ,Finland

25. Amuado-Dorantes, C., and Pozo, S., (2005). On the Use of Differing Money Transmission Methods by Mexican Immigrants. The International Migration Review. 39(3).

مجلة الاراسات التجارية المعاصرة"


26. Ahmed, I., (2000). Remittances and their Economic Impact on Post-War Somaliland. Disasters. 24(4).

27. Yang, D., (2004). International Migration, Human capital and Entrepreneurship: Evidence from Philippine Migrants Exchange Rate Shocks. Ford School for Public Policy, Working Paper.

28. Shivani, P., Tineke, R., (2000). Migrant Worker Remittances. Micro-Finance and the Information Economy: Prospects and Issues. Working Paper (21).

29. Glytsos, N.P., (2005).The Contribution of Remittances to Growth. A Dynamic Approach and Empirical Analysis. Journal of Economic Studies. 32(6).

30. Ratha, D., (2006). Trends, Determinants and Macroeconomic Effects of Remittance. In Global Economics Prospects 2006: Economic Implications of Remittances and Migration, World Bank, Washington, D.C.

31. Ang Alvin P., (2007). Workers' Remittances and Economic Growth in the Philippines. Social Research Center, University of Santo Tomas, Philippines, (1015).

32. Taparia V., (2005), Banking across Borders, Texas Business Review, February, 1-6.

33. Bugamelli, M., Paterno, F., (2005). Do Workers' Remittances Reduce the Probability of Current Account Reversals?.World Bank Policy Research Working Paper (3766).

34. Gyan, P., Mukti, U., Kamal, U., (2008). Remittances and Economic Growth in Developing Countries. The European Journal of Development Research. 20(3). September.

35. Ravshanber A., (2011), Impact of Remittances on Economic growth in selected Asian and Former Soviet Union countries, Master thesis, School of Economics and Management, Lund University, Sweden.

36. Adams R. H., (2004), Remittances and poverty in Guatemala, World Bank Policy, Research Working Paper. (3418)

37. Eken, S., (2005), Macroeconomic Impact of Remittances, in Migration, Remittances and Development, OECD, Paris

38. Chami R., Fullenkamp C., Samir J., (2003). Are Immigrant Remittance Flows a Source of Capital for Development?. IMF staff papers.52 (1).

39. Glytsos, N.P., (1993), Measuring the income effects of migrant remittances: A methodological approach applied to Greece, Economic Development \& Cultural Change, 42(1)

40.Edwards, A., Ureta, M.,(2003), International Migration, Remittances and Schooling: Evidence from El Salvador. Journal of Economic Developments, (72).

مجلة الاراسات التجارية المعاصرة


41. Yang, D., (2004). International Migration, Human capital and Entrepreneurship: Evidence from Philippine Migrants Exchange Rate Shocks. Ford School for Public Policy, Working Paper.

42. Osili Una, (2007), Understanding Migrants' Remittances: Evidence from the U.S.-Nigeria Migration Survey, International Migration Program of the Social Science Research Council, Indiana University Purdue, India.

43. Woodruff, C. and R. Zenteno (2007), Remittances and Microenterprises in Mexico, Mimeo.

44. Osili Una, (2007), Understanding Migrants' Remittances: Evidence from the U.S.-Nigeria Migration Survey, International Migration Program of the Social Science Research Council, Indiana University Purdue, India.

45. Nemat Shafik, (1995). Multiple Trade Shocks \& Partial Liberalization: Dutch Disease \& the Egyptian Economy. Economic Research Forum, World Bank, Working paper, (9503), Washington, D.C.

46. Amuado-Dorantes, C., and Pozo, S.,(2004),Workers' Remittances and the Real Exchange Rate: A Paradox of Gifts, World Development,32(8)

47. Rajan, Raghuram, and Arvind Subramanian, (2005), What Undermines Aid's Impact on Growth?, NBER Working Paper (11657)

48. Ratha, D., (2006). Trends, Determinants and Macroeconomic Effects of Remittance. In Global Economics Prospects 2006: Economic Implications of Remittances and Migration, World Bank, Washington, D.C.

49. Bourdet, Y., and Falck, H. (2006), Emigrants' remittances and Dutch Disease in Cape Verde, International Economic Journal, 20(3)

50. Elbadawi, I. A., Rocha, D. R., (1992). Determinants of Expatriate Workers' Remittances In North Africa and Europe. World Bank Working Paper.(1038), World Bank .Washington DC.

51. Katseli, L. and Glytsos, N. (1986), Theoretical and Empirical Determinants of International Labor Mobility: A Greek-German Perspective, Centre for Economic Policy Research Working Paper,(148)

52. Obstfeld, M. and K. Rogoff (1996): Foundations of International Macroeconomics, MIT press.

53. Ghosh, B., (2006). Migrants, Remittances and Development: Myths, Rhetoric and Realities. International Organization for Migration (IOM), Geneva.

مجلة الاراسات التجارية المعاصرة


54. Acosta, Pablo A., Emmanuel K.K. Lartey, and Federico S. Mandelman, (2007), Remittances and the Dutch Disease, Working Paper (8), Federal Reserve Bank of Atlanta, Atlanta.

55. Bugamelli, M., Paterno, F., (2005). Do Workers' Remittances Reduce the Probability of Current Account Reversals? World Bank Policy Research Working Paper (3766).

56. Central Agency for Public Mobilization and Statistics (CAPMS), (2010). The Statistical Yearbook, Egypt.

57. Thomas E., (1997), Testing for multi-cointegration, Economics letter,(65).

58. Granger, C.W.J. and Newbold, P.,(1974),Spurious Regression in Econometrics, Journal of Econometrics, (2)

59. Dickey, D., Fuller, W., (1979). Distribution of the Estimators for Autoregressive Time Series with a Unit Root. Journal of the American Statistical Association. (74).

60. Green, Joshua, and Delano Villanueva, (2002), Private Investment in Developing Countries: An Empirical Analysis, IMF Staff Papers, 38(1), March

61. Gonzalo, C., (1994). Five Alternative Methods of Estimating Long-Run Equilibrium Relationship. Journal of Econometrics, (60).

62. Engle, R. F., Granger, C. W., (1987). Cointegration and Error Correction: Representation. Estimation and Testing. Econometrica. $55(2)$

63. Johanssen, N Kaijage, (2008). The Impacts of International Remittances on Receiving Countries at the Micro and Macro Level and Policy Options for Increasing Remittance Effectiveness: Reviewing the Literature. Master Thesis, Maastricht Graduate School of Governance, Maastricht University, Netherland. 


\section{Appendix}

\section{Econometrics variables}

\begin{tabular}{|c|c|c|c|c|c|c|}
\hline obs & WR & $\mathbf{L}$ & I & G & FDI & $\mathbf{Y}$ \\
\hline 1991 & 20.00000 & 43.20000 & 21.20000 & 11.20000 & 0.648000 & 1.079000 \\
\hline 1992 & 10.50000 & 42.00000 & 19.50000 & 10.40000 & 1.097000 & 4.432000 \\
\hline 1993 & 12.30000 & 41.50000 & 19.80000 & 10.30000 & 1.058000 & 2.901000 \\
\hline 1994 & 7.800000 & 42.30000 & 20.60000 & 10.20000 & 2.420000 & 3.973000 \\
\hline 1995 & 6.900000 & 41.20000 & 20.10000 & 10.50000 & 0.994000 & 4.642000 \\
\hline 1996 & 5.200000 & 41.80000 & 18.10000 & 10.30000 & 0.940000 & 4.989000 \\
\hline 1997 & 5.200000 & 41.60000 & 17.60000 & 11.30000 & 1.135000 & 5.491000 \\
\hline 1998 & 5.400000 & 41.20000 & 21.50000 & 11.30000 & 1.268000 & 4.036000 \\
\hline 1999 & 5.300000 & 42.60000 & 21.60000 & 11.60000 & 1.174000 & 6.105000 \\
\hline 2000 & 4.600000 & 41.90000 & 19.50000 & 11.20000 & 1.237000 & 5.368000 \\
\hline 2001 & 3.800000 & 41.40000 & 18.20000 & 11.30000 & 0.522000 & 3.535000 \\
\hline 2002 & 4.800000 & 40.60000 & 17.90000 & 12.60000 & 0.736000 & 2.370000 \\
\hline 2003 & 4.300000 & 41.00000 & 16.90000 & 12.7 & 5000 & 3.192000 \\
\hline 2004 & 4.900000 & 42.20000 & 16.90000 & 12.80000 & 1.590000 & 4.090000 \\
\hline 2005 & 6.000000 & 42.60000 & 17.90000 & 12.70000 & 5.994000 & 4.479000 \\
\hline 2006 & 5.200000 & 42.10000 & 18.70000 & 12.30000 & 9.34 & 6.854000 \\
\hline 2007 & 5.400000 & 43.90000 & 20.80000 & 11.30000 & 8.874000 & 7.090000 \\
\hline 2008 & 5.700000 & 44.20000 & 22.40000 & 10.80000 & 5.831000 & 7.158000 \\
\hline 2009 & 4.300000 & 44.20000 & 19.20000 & 11.30000 & 3.551000 & 4.674000 \\
\hline 2010 & 4.700000 & 44.80000 & 19.50000 & 11.10000 & 2.917000 & 5.145000 \\
\hline 2011 & 5.500000 & 43.00000 & 17.10000 & 11.40000 & -0.205000 & 1.780000 \\
\hline 2012 & 6.500000 & 42.80000 & 16.20000 & 11.30000 & 1.001000 & 2.216000 \\
\hline 2013 & 6.600000 & 42.80000 & 14.30000 & 11.40000 & 1.453000 & 2.185000 \\
\hline 2014 & 9.900000 & 42.80000 & 13.80000 & 12.00000 & 1.566000 & 2.916000 \\
\hline 2015 & 6.500000 & 43.20000 & 14.30000 & 11.80000 & 2.069000 & 4.372000 \\
\hline 2016 & 5.000000 & 43.70000 & 15.04000 & 11.40000 & 2.436000 & 4.298000 \\
\hline
\end{tabular}

